\title{
Partial Purification and Characterization of Bacteriocin-like Peptide Produced by Staphylococcus xylosus
}

\author{
Veslava Matikevičienè ${ }^{1,2}$, Saulius Grigiškis ${ }^{1}$, Erika Lubytè ${ }^{1}$, Gervydas Dienys ${ }^{2}$ \\ ${ }^{1} J S C$ Biocentras. Address: Graičiüno g. 10, Vilnius, LT-02241, Lithuania. \\ ${ }^{2}$ Vilnius University, Institute of Biotechnology, Sector of Applied Biocatalysis. Address: Sauletekis al. 7, Vilnius, \\ LT- 10257, Lithuania.
}

\begin{abstract}
The extensive use of antibiotics leads to an increasing number of antibiotic-resistant pathogenic microorganisms. The development of new antimicrobials is needed for clinical, veterinary, and food applications. Bacteriocins are small peptides with antimicrobial activity ribosomally synthesized by bacteria and could be applied as an alternative to classical antibiotics. In this study, the bacteriocin-like (BLIS) peptide, produced by Staphylococcus xylosus was partially purified and main characteristics ( $\mathrm{pH}$, thermal stability, resistance to some protease enzymes and molecular weight) were evaluated. Ammonium sulfate precipitation, acetone extraction and ion-exchange chromatography methods were applied for purification of bacteriocin. The activity of bacteriocin was detected using a well diffusion assay method and the amount of protein concentration was estimated by Lowry method. Molecular weight ( 6 kDa) of purified bacteriocin was determined by sodium dodecyl sulphate polyacrilamide gel electrophoresis (SDS PAGE) method. The highest purification yield (80 \%) was obtained using ion-exange chromatography and SP-sepharose as sorbent. The purified bacteriocin remained stable at $\mathrm{pH}$ values between 2.0 and 12.0 for $4 \mathrm{~h}$. No decrease in antibacterial activity was estimated after 30 min at $121^{\circ} \mathrm{C}$ temperature. The purified bacteriocin was resistant to papain, pepsin and trypsin action. The BLIS inhibits a growth of Listeria monocytogenes $(93 \pm 3.0 \%)$, Bacillus subtilis $(85 \pm 4.0 \%)$, Pediococcus pentosaceus (79 $\pm 4.0 \%)$, Staphylococcus aureus $(51 \pm 5.0 \%)$ and Propionibacterium acnes $(70 \pm 5 \%)$ up to 24 hours. Such bacteriocin preparation could be applied as antimicrobial agent in medical and food industry.
\end{abstract}

Keywords: antimicrobial agent, bacteriocin, purification, Staphylococcus xylosus.

\section{INTRODUCTION}

An extensive use of broad-spectrum antibiotics in a treatment of human and animal diseases promotes the growing of antibiotic resistant pathogenic bacteria. In recent years the development of new antimicrobial agents has become of increasing importance for medicine, veterinary and food industry [1].

Bacteriocins are natural peptides or small proteins ribosomally synthesized and secreted in the living environment by many varieties of bacteria and some archae for the purpose of killing other bacteria [2], [3]. These antimicrobial peptides are usually characterized by a narrow spectrum of activity targeting only close related species. However, some of them (mostly synthesized by gram-positive bacteria) show very broad inhibitory spectra and even inhibit spore germination [3], [4].

Bacteriocins are divided into different groups based on their variable structural, physicochemical and molecular characteristics [5]. A number of different bacteriocins classification principles are described in the literature; however, most authors distinguish bacteriocins into three main classes: Class I (lantibiotics) - after the broadcast modified peptides;
Class II (non-lantibiotics) - heat-resistant, minimally modified peptides; Class III - heat-labile and large molecular mass bacteriocins [6].

A considerable number of bacteriocin-like substances have been reported in the literature but only a few of them have been isolated and thoroughly characterized. The bacteriocin purification procedure often involves a few steps which are quite long and time-consuming. The precipitation, ion exchange chromatography and reversed-phase chromatography are the main techniques used by different authors.

In this study the bacteriocin-like peptide (BLIS), produced by Staphylococcus xylosus was partially purified and same characteristics were determined.

\section{MATERIALS AND METHODS}

Microorganisms and Media

Staphylococcus xylosus strain was obtained from JSC "Biocentras" microorganisms' collection and was used for production of bacteriocin-like peptide. Listeria monocytogenes strain was used for evaluation of bacteriocin activity as an indicator strain. Oxoid mineral medium was used for cultivation of L. monocytogenes. Solid medium was produced by supplementing $1.5 \%$ of agar to the

ISSN 1691-5402

(C) Rezekne Academy of Technologies, Rezekne 2017 http://dx.doi.org/10.17770/etr2017vol3.2586 
broth. Bacteriocin production was investigated in basal medium composed of meat extract, triptone, glucose, $\mathrm{K}_{2} \mathrm{HPO}_{4}$ and $\mathrm{NaCl}$ in $500 \mathrm{~mL}$ Erlenmeyer flasks for $18 \mathrm{~h}$ at $30^{\circ} \mathrm{C}$ and $200 \mathrm{rpm}$.

\section{Experimental procedure}

Cell-free $S$. xylosus culture supernatant was collected by centrifugation at $10,000 \times \mathrm{g}$ for $20 \mathrm{~min}$ at $4{ }^{\circ} \mathrm{C}$ temperature. The $\mathrm{pH}$ of the supernatant was adjusted to $6.0 \pm 0.5$ with $0.1 \mathrm{M} \mathrm{NaOH}$ or $0.1 \mathrm{M}$ $\mathrm{H}_{3} \mathrm{PO}_{4}$. The supernatant was filtered through a $0.20 \mu \mathrm{m}$ pore size cellulose acetate syringe filter. Ammonium sulphate precipitation, acetone extraction and ion-exchange chromatography methods were applied for purification procedure.

Purification of bacteriocin

Partial purification of the sample was done by adding $\left(\mathrm{NH}_{4}\right)_{2} \mathrm{SO}_{4}$ at $80 \%$ of saturation level, followed by dialysis for $12 \mathrm{~h}$. The pellet was collected after centrifugation at $10,000 \times \mathrm{g}$ at $4{ }^{\circ} \mathrm{C}$ for $30 \mathrm{~min}$. The pellet was dissolved in phosphate buffer (0.1 M, pH 7.0) and stored at $4{ }^{\circ} \mathrm{C}$ for further use.

Acetone extraction. Four times the sample volume of cold $\left(-20^{\circ} \mathrm{C}\right)$ acetone was added to the cooled sterile supernatant sample $\left(4^{\circ} \mathrm{C}\right)$, mixed for $15 \mathrm{~min}$ and incubated $60 \mathrm{~min}$ at $4{ }^{\circ} \mathrm{C}$. The pellet was collected by further centrifugation. The bacteriocin pellet was dissolved in in phosphate buffer $(0.1 \mathrm{M}$, $\mathrm{pH}$ 7.0) and stored at $4{ }^{\circ} \mathrm{C}$ for further use.

Ion exchange chromatography. Prepared supernatant sample was applied on SP sepharose column $(1.6 / 20 \mathrm{~cm})$ equilibrated with $0.02 \mathrm{~mol} / \mathrm{L}$ sodium phosphate buffer $(\mathrm{pH} 5.0)$ and eluted with same buffer using linear salt gradient of $\mathrm{NaCl}(0-$ $1 \mathrm{~mol} / \mathrm{L})$. The active fractions were pooled together.

Bactericidal activity. The inhibition of indicator strains was detected using agar well diffusion assay [7]. The solid MRS agar medium pre-inoculated with the indicator microorganism was prepared and wells of $9 \mathrm{~mm}$ diameters were cut. The prepared supernatant was placed in wells and plates were incubated at $37{ }^{\circ} \mathrm{C}$ for $24 \mathrm{~h}$. Positive results, the inhibitory of grow of indicator microorganisms, were assessed by measuring a clear zone around the well in the vertical and horizontal direction by using a calliper. Measurements were done in duplicate and an average was calculated.

Soluble proteins. The amount of soluble bacteriocins was evaluated using modified Lowry method [8].

\section{Characterisation of bacteriocin}

SDS-PAGE was run to check the purity of the sample as well as to determine molecular mass of the sample. The gel used for the separation was $16.0 \%$ tris-tricine SDS-PAGE and the ladder used was PageRuler Unstained Low Range protein ladder (Thermo Scientific). The gel was subjected to $25 \mathrm{~mA}$ for $120 \mathrm{~min}$ and then stained with Coomassie brilliant blue R 250 (Merck).
The effect of $\mathrm{pH}$ on bacteriocin activity was evaluated by adjusting the $\mathrm{pH}$ between 2.0 and 12.0 with sterile $1 \mathrm{~mol} / \mathrm{L} \mathrm{NaOH}$ or $1 \mathrm{~mol} / \mathrm{L} \mathrm{H}_{3} \mathrm{PO}_{4}$ and by further incubating for $4 \mathrm{~h}$ at $30{ }^{\circ} \mathrm{C}$. The temperature effect on activity of the purified bacteriocin was tested by incubating at various temperatures (30, 40, $50,60,70,80,100^{\circ} \mathrm{C}$ ) and the residual activity was determined after $60 \mathrm{~min}$ and after $30 \mathrm{~min}$ at $121{ }^{\circ} \mathrm{C}$. Samples were also stored for 28 days at $-20,4$, and $40{ }^{\circ} \mathrm{C}$ and were assayed for antimicrobial activity at 1 -week intervals.

Samples of the purified bacteriocin were treated with the following enzymes $(2 \mathrm{mg} / \mathrm{mL})$ and incubated for $2 \mathrm{~h}$ at $37{ }^{\circ} \mathrm{C}$ : papain, trypsin and pepsin. Antimicrobial activity was monitored by using the agar well diffusion assay.

\section{RESULTS AND DISCUSSION}

Staphylococcus xylosus secretes to the growing media bacteriocin-like peptide, that inhibits the grow of many Gram positive bacteria. Three methods of protein purification were applied during the study. Yields of purification processes are presented in Table I.

Table I

Summary of the purification processes of bacteriocin from culture supernatant of S. xylosus

\begin{tabular}{|l|c|c|c|c|c|}
\hline Sample & $\begin{array}{c}\text { Total } \\
\text { activity, } \\
\text { (U) }\end{array}$ & $\begin{array}{c}\text { Total } \\
\text { protein, } \\
\text { (mg) }\end{array}$ & $\begin{array}{c}\text { Specific } \\
\text { activity, } \\
\text { (U/mg) }\end{array}$ & $\begin{array}{c}\text { Purifi } \\
\text { cation } \\
\text { (Fold) }\end{array}$ & $\begin{array}{c}\text { Yield, } \\
\%\end{array}$ \\
\hline $\begin{array}{l}\text { Culture } \\
\text { supernatant }\end{array}$ & 38500 & 3570 & 10.8 & 1 & 100 \\
\hline $\begin{array}{l}\left.\mathrm{NH}_{4}\right)_{2} \mathrm{SO}_{4} \\
\text { precipitate }\end{array}$ & 4801 & 318 & 15.1 & 1.4 & 10.6 \\
\hline $\begin{array}{l}\text { Acetone } \\
\text { extract }\end{array}$ & 20290 & 719.5 & 28.2 & 2.6 & 52.7 \\
\hline $\begin{array}{l}\text { SP } \\
\text { sepharose }\end{array}$ & 30916 & 203.0 & 152.3 & 14.1 & 80.3 \\
\hline
\end{tabular}

The obtained results showed, that the ammonium sulphate fractionation provided low yield with low specific activity and fold purification. The high purification yield with low specific activity was obtained during the cold-acetone precipitation. But sufficiently pure preparation of bacteriocin, with high specific activity and fold purification, was determined using ion exchange chromatography and SPsepharose as sorbent. The purified preparation yielded a single protein band on SDS-PAGE with a molecular weight about $6.0 \mathrm{kDa}$ (Fig. 1).

The different purification techniques are described in the literature. Mesentericin Y105, produced by Leuconosto mesenteroides Y105, was purified using three-step method (carboxy-methyl-cellulose-filled column $(2.5$ by $18 \mathrm{~cm})$, followed by a $\mathrm{C}_{18}$ cartridge and $\mathrm{C}_{8}$ Kromasil analytical HPLC column) and the $60 \%$ yield of recovery activity was obtained [9]. Bacteriocin, leucocin A-UAL 187 has been purified by ammonium sulfate or acid $(\mathrm{pH} 2.5)$ precipitation, hydrophobic interaction chromatography, gel filtration, and reversed-phase high-performance 
liquid chromatography with a yield of $58 \%$ of the original activity [10].

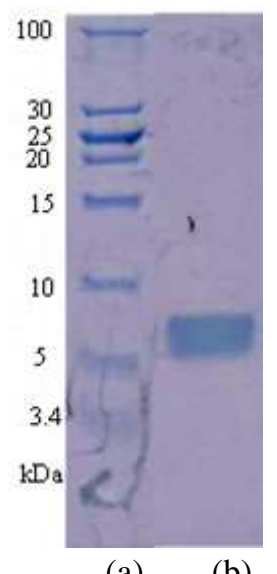

(a)
The long term (28 days) bacteriocin stability studies shown (Table 2), that the solution of purified bacteriocin was stable at $-20{ }^{\circ} \mathrm{C}$ and $4{ }^{\circ} \mathrm{C}$ temperature and maintained about $100 \%$ of its activity. More than $80 \%$ of activity was retained at $40{ }^{\circ} \mathrm{C}$ after 28 days.

The purified bacteriocin preparation was resistant to papain, pepsin and trypsin action. No significant effect on residual activity of bacteriocin was evaluated.

Table II

The stability of bacteriocin solution

\begin{tabular}{|c|c|c|c|}
\hline \multirow{2}{*}{$\begin{array}{c}\text { Time, } \\
\text { days }\end{array}$} & \multicolumn{3}{|c|}{ Residual bacteriocin activity $(\%)$ at different } \\
& \multicolumn{3}{|c|}{ temperatures $\left({ }^{\circ} \mathrm{C}\right)$} \\
\cline { 2 - 4 } & $-20 \pm 2$ & $4 \pm 1$ & $40 \pm 2$ \\
\hline 0 & 100 & 100 & 100 \\
\hline 3 & $98,4 \pm 1,4$ & $98,3 \pm 1,5$ & $77,0 \pm 6,7$ \\
\hline 7 & $97,6 \pm 2,8$ & $96,6 \pm 3,1$ & $54,6 \pm 3,3$ \\
\hline 14 & $98,7 \pm 2,5$ & $98,2 \pm 2,0$ & $28,1 \pm 1,4$ \\
\hline 21 & $98,9 \pm 3,1$ & $90,3 \pm 3,7$ & $17,9 \pm 1,8$ \\
\hline 28 & $99,3 \pm 1,1$ & $88,9 \pm 3,5$ & $7,3 \pm 1,5$ \\
\hline
\end{tabular}

Some studies of characterization of bacteriocins show the similar results. The bacteriocins ST28MS and ST26MS produced by Lactobacillus plantarum isolated from molasses remained stable after incubation for $2 \mathrm{~h}$ at $\mathrm{pH}$ values between 2.0 and 12.0. No decrease in antibacterial activity was recorded after $90 \mathrm{~min}$ at $100^{\circ} \mathrm{C}$ or $20 \mathrm{~min}$ at $121^{\circ} \mathrm{C}$ [11]. Weissellin A, produced by Weissella paramesenteroides DX, retained its activity after exposure to $121{ }^{\circ} \mathrm{C}$ for $60 \mathrm{~min}$ or to $-20{ }^{\circ} \mathrm{C}$ for 6 months, and to $\mathrm{pH} 2.0-10.0$. It was not sensitive to trypsin, a-chymotrypsin, pepsin and papain [12]. Acidocin, produced by L. acidophilus DSM 20079, has been characterized as a one-component peptide of low molecular weight $(6.6 \mathrm{kDa})$, extremely heatstable and active over a wide $\mathrm{pH}$ range, although with a narrow inhibitory activity spectrum [1].

Bacteriocins are usually only active against bacteria related to the producer although some may affect a wide range of other Gram-positive organisms and even inhibit spore germination.

TABLE III

Antibacterial activity of purified bacteriocin against various bacteria

\begin{tabular}{|l|c|}
\hline Microorganism & Inhibition, after $24 \mathrm{~h}$ \\
\hline Listeria monocytogenes & $93 \pm 3,0$ \\
\hline Bacillus subtilis & $85 \pm 4,0$ \\
\hline Pediococcus pentosaceus & $79 \pm 4,0$ \\
\hline Staphylococcus aureus & $51 \pm 5,0$ \\
\hline Propionibacterium acnes & $70 \pm 5,0$ \\
\hline
\end{tabular}


In this study the inhibitory spectrum of purified bacteriocin from $S$. xylosus was determined. It effectively inhibits a growth of many Gram positive bacteria up to 24 hours (Table III). The highest inhibitory activity against Listeria monocytogenes and lowest against $S$. aureus was evaluated.

The bacteriocin isolated from Weissella confusa A3 was shown the inhibitory activity towards Bacillus cereus, Escherichia coli, Pseudomonas aeruginosa and Micrococcus luteus[13]. The purified bacteriocin of L. murinus AU06 was shown to have the significant antibacterial activity against Micrococcus sp., Staphylococcus aureus, Pseudomonas aeruginosa and Escherichia coli whereas lower inhibition found with Enterococcus faecalis, Bacillus licheniformis and Listeria monocytogenes [5].

\section{CONCLUSION}

The bacteriocin isolated from Staphylococcus xylosus cell-free supernatant was purified using ion exchange chromatography with a yield of $80 \%$ of the specific activity and characterized. The purified bacteriocin was shown to be heat stable and active at broad $\mathrm{pH}$ range. The purified bacteriocin exhibited various levels of activity against all gram-positive bacteria tested. The properties of bacteriocin and the ability in inhibiting a wide-range of pathogenic bacteria make it a potentially suitable agent for food and medical industry.

\section{REFERENCES}

[1] J. L. Parada, C. R. Caron, A. P. Medeiros and C. R. Soccol, "Bacteriocins from Lactic Acid Bacteria: Purification, Properties and use as Biopreservatives", Brazilian Archives of Biology and Technology, vol.50, n. 3, pp.521-542, May 2007.

[2] Alvarez-Sieiro, P., Montalbán-López, M., Mu, D., \& Kuipers, O. P. (2016). Bacteriocins of lactic acid bacteria: extending the family. Appl. Microbiol. Biotechnol., 100 (7), pp. 29392951.
[3] Martínez, B., Rodríguez, A., \& Suárez, E. (2016). Antimicrobial Peptides Produced by Bacteria: The Bacteriocins. In New Weapons to Control Bacterial Growth (pp. 15-38). Springer International Publishing.

[4] H. Holo, T. Fayec, D. Bredea, T. Nilsena, I. Ødegårdb, Th. Langsrudc, J. Brendehaugb, I. F. Nes, Bacteriocins of propionic acid bacteria. Lait 82 (2002) 59-68, Oral communication at the 3rd International Symposium on Propionibacteria, Zurich, Switzerland, July 8-11, 2001.

[5] S. Elayaraja, N. Annamalai, P. Mayavu, T. Balasubramanian, "Production, purification and characterization of bacteriocin from Lactobacillus murinus AU06 and its broad antibacterial spectrum", Asian Pac J Trop Biomed, vol. 4(Suppl 1), pp. S305-S311, 2014.

[6] V. Kaškonienè, M. Stankevičius, K.Bimbiraitè-Survilienè, G. Naujokaitytė, L. Šernienè, K. Mulkytė, M. Malakauskas, A. Maruška, "Current state of purification, isolation and analysis of bacteriocins produced by lactic acid bacteria", Appl Microbiol Biotechnol, vol. 101, pp. 1323-1335, 2017.

[7] D. Cizeikiene, G. Juodeikiene, A. Paskevicius, E, Bartkiene, "Antimicrobial activity of lactic acid bacteria against pathogenic and spoilage microorganism isolated from food and their control in wheat bread", Food Control, vol. 31(2), pp. 539-545, 2013.

[8] J. H. Waterborg, The Lowry Method for Protein Quantitation. The Protein Protocols Handbook, 2nd Edition. Humana Press, 2002, pp. 7-9.

[9] Guyonnet, D.; Fremaux, C.; Cenatiempo, Y. and Berjeaud, J. M., "Method for rapid purification of class IIa bacteriocins and comparison of their activities. Appl. Environ. Microbiol., vol. 66, pp. 1744-1748, 2000.

[10] J. W. Hastings, M. Sailer, K. Johnson, K. L. Roy, J. C. Vederas, and M. E. Stiles, "Characterization of leucocin AUAL 187 and cloning of the bacteriocin gene from Leuconostoc gelidum", J. Bacteriol., 173, pp. 7491-7500, 1991.

[11] S. D. Torodov, L. M. T. Dicks, "Lactobacillus plantarum isolated from molasses produces bacteriocins active against Gram-negative bacteria”. Enzyme and Microbial. Technol., vol. 36, pp. 318-326, 2005.

[12] M. Papagianni, E. M. Papamichael, "Purification, amino acid sequence and characterization of the class IIa bacteriocin weissellin A, produced by Weissella paramesenteroides DX", Bioresource Technology, vol. 102, pp. 6730-6734, 2011.

[13] H. F. Goh, K.Philip, "Purification and Characterization of Bacteriocin Produced by Weissella confusa A3 of Dairy Origin", PLoS ONE 10(10): e0140434. doi:10.1371/journal.pone.0140434 